\title{
КОМПРЕСІЙНА АСФІКСІЯ
}

\author{
к.м.н. Хоботова Наталія Володимирівна \\ Украӥна. м.Дніпро. \\ ДЗ "Дніпропетровська медична академія МОЗ України" \\ асистент кафедри оториноларингології
}

к.м.н. Схалов Василій Вталійович

Украӥна. м.Дніпро.

ДЗ "Дніпропетровська медична академія МОЗ Украӥни"

доцент кафедри анестезіології, інтенсивної терапії і медицини невідкладних станів ФПО.

\section{DOI: https://doi.org/10.31435/rsglobal_wos/30112019/6805}

\section{ARTICLE INFO}

Received: 29 September 2019

Accepted: 16 November 2019

Published: 30 November 2019

\section{KEYWORDS}

chest and abdominal compression, traumatism,

upper vena cava syndrome,

pathomorphology,

pathophysiology,

intensive care.

\begin{abstract}
Compression asphyxia is a type of mechanical asphyxia when breathing stops with external pressure on the body, which leads to the absence of respiratory movements and disrupts venous return from the head. With a strong compression of the chest, a reflex spasm of the glottis occurs, which contributes to an increase in intrathoracic pressure, reverse venous blood flow and an obstruction of venous flow to the heart occur. A sharp increase in intracranial pressure and venous congestive congestion / hemorrhage deepen central respiratory failure. Mild degree: mental agitation; puffy face, slight cyanosis; individual conjunctival petechiae; tachypnea. Medium degree: light or heavy stunning, lost orientation; the face is puffy, cyanotic; swelling of the cervical veins, acrocyanosis; multiple petechiae that spread across the face, neck, conjunctiva of the eyes, inspiratory dyspnea, visual impairment. Severe degree: stupor or coma, sharp cyanosis of the whole body, exophthalmos; swelling of the face, neck and shoulder girdle, arms, multiple petechiae of the face, neck, arms, legs, conjunctiva of the eyes, swelling of the cervical veins, cyanosis and edema of the upper half of the body; superficial breathing, frequent, in the absence of treatment passes to agonal and apnea. Intensive care includes analgesia, oxygenation or mechanical ventilation, anticonvulsant, dehydration and decongestant therapy, prevention of acute kidney damage, DIC, septic complications, and treatment of posthypoxic encephalopathy.
\end{abstract}

Citation: Хоботова Н. В., Схалов В. В. (2019) Kompresiina Asfiksiia. International Academy Journal Web of Scholar. 11(41), Vol.1. doi: 10.31435/rsglobal_wos/30112019/6805

Copyright: (C) 2019 Хоботова Н. В., Схалов В. В. This is an open-access article distributed under the terms of the Creative Commons Attribution License (CC BY). The use, distribution or reproduction in other forums is permitted, provided the original author(s) or licensor are credited and that the original publication in this journal is cited, in accordance with accepted academic practice. No use, distribution or reproduction is permitted which does not comply with these terms.

Актуальність. Компресійна асфіксія (синдром Олів'є, Пертеса, , хвороба Єлисейських полів) - $є$ різновидом механічної асфіксії, коли дихання припиняється при зовнішньому тиску на тіло, що призводить до відсутності дихальних рухів і порушує венозний повернення 3 голови. Такий вид механічної асфіксії спостерігається у випадках, коли відсутня наявність грубої анатомічної травми скелета, внутрішніх органів грудної та черевної порожнин.

Стискання грудей і живота - вид компресійної механічної асфіксії, який виникає внаслідок обмеження дихальних екскурсій легенів і порушення кровообігу від сильного тиску на грудну клітку та черево.

(* Використання терміну доцільно тільки у випадках, коли компресія тулуба не призводить до множинних переломів кісток, розривів внутрішніх органів і інших грубих пошкоджень). 
У мирний час травматична асфіксія зустрічається у $0,2 \%$ всіх хворих 3 травмами, а при закритих пошкодженнях грудної клітини і тулуба від 1,1 до 11,6\% випадків. Смертельні випадки від компресії грудей і живота складають $0,5-0,7 \%$ від механічної асфіксії. Чоловіки гинуть від компресії грудей та черева більш ніж в 2 рази частіше за жінок (68\% проти $32 \%)$. Найбільш часта така причина смерті у вікових групах $31-40$ років (24\%) та 41-50 років (22\%), найбільш рідко (поодинокі випадки) - в дитячому віці. На інші вікові групи припадає по 6-10\%. Випадки поза виробництвом - $42 \%$, у зв'язку з виробництвом - $58 \%$.

Причини. Найбільш часто стискання тіла спричиняється транспортними засобами (до 50\%): при перекиданні автомобілів і тракторів, при їх русі заднім ходом, при зчепленні трамваїв і поїздів, тощо:

1) Попадання до стрічкопротягувальних механізмів, трансмісій або під різні підйомники.

2) Вихід з ладу або несправність спеціальних механізмів та пристроїв: відмова домкратних та елеваторних систем на будівництві, при ремонті автомобілів, при вантажних та монтувальних роботах, тощо.

3) Потрапляння людини до камери тюкування сіна або соломи.

4) Падіння на людину важких меблів, торгових автоматів, тощо.

5) Природні або антропогенні аварії та катастрофи: землетруси, вибухи; обвалення землі, порід або вугільних паків у шахтах, тунелях, нещасні випадки з шахтарями, спелеологами, дігерами; засипання будматеріалами, зерном, тощо; дорожньо-транспортні пригоди; панічна тіснява та тривале стискання в натовпі (синдром затоптування, «ходинка»): горизонтальні сили, достатні для того, щоб викликати компресійну асфіксію, найбільш динамічні, тому що люди відштовхуються один від іншого, щоб отримати перепочинок (G. Keith Still, 2017); смерть через асфіксію 3 такої причини зветься "riot-crush", тобто "страйк-руйнування".

6) Потрапляння людини до вузького лазу, колодязя, вентиляційної шахти, тощо.

7)Нещасні випадки зі спортсменами: притискання грифом штанги, тілами гравців у регбі, тощо.

8) Недодержання правил техніки безпеки на виробництві, при користуванні транспортом, на відпочинку, тощо.

9) Глибоководний дайвінг.

10) Епілептичні напади.

11) Важкі пологи.

12) Астматичний напад.

13) Неналежний догляд за дітьми та особами з обмеженими можливостями: занадто туге сповивання дітей; стискання тулуба немовляти уві сні частиною тіла дорослої людини (дихальні рухи можуть припинитися під вагою кисті та передпліччя покладених на груди); потрапляння та фіксація тіла між близько розташованими предметами меблів.

14) Кримінальні наміри іншої особи: вбивство шляхом стискання грудної клітки, коли злочинець (кат) стає на коліна або сидить усією вагою свого тіла на іншому тривалий час; зашивання людини у свіжу шкуру тварин, яка повільно підсихає і стискає тіло ("taze cilt"); при підвішуванні тіла у вертикальній позі (самостійно підвішені або прив'язані положення з опущеною головою для аутоеротичних задоволень $є$ прикладами випадкової або суїцидальної позиційної асфіксії); закопування живими у землю або сипучі речовини високої щільності.

15) Як ексклюзивні випадки: притискання тілом слона, напад на людину великого пітона або анаконди.

Науково-практична новизна. У доступних спеціальних літературних джерелах за темою "асфіксія внаслідок стискання грудей та/або черева" у переважній кількості наведені питання посмертної судово-медичної експертизи, в той же час недостатньо уваги приділено патогенезу, діагностиці та основам надання медичної допомоги таким постраждалим. Оскільки досі не існує діючого клінічного протоколу діагностики та лікування при таких травмах, на підставі одиничних вітчизняних та зарубіжних науково-дослідницьких робіт, особистого теоретичного і клінічного досвіду ми розробили алгоритм діагностики та медичної допомоги на етапах маршруту потерпілого.

\section{Матеріали та методи.}

Механізми ураження при компресійній асфіксії. При швидкому сильному стисненні грудей виникає рефлекторний спазм голосової щілини, що сприяє збільшенню внутрішньогрудного тиску, виникають зворотний венозний кровоток та перешкода венозному притоку до серця, також розвинення синдрому верхньої порожнистої вени; капілярний стаз, перерозтягування та розрив 
капілярів; різке збільшення центрального венозного тиску; різке обмеження життєвої ємності легенів спричиняє гіпоксичну (респіраторну) гіпоксію. Щоб зупинити грудне дихання достатньо маси 40-50 кг (для фізично міцних людей - 80-100 кг). Форсоване стиснення грудної клітини та живота ускладнюється механічним ушкодженням легень: розривами міжальвеолярних перетинок та легеневої тканини, крововиливами, "карміновим" набряком, ателектазуванням, утворенням повітряних бульбашок у плевральних порожнинах, тощо. Стимулююча дія СО2 на ЦНС змінюється на депресивну, відому як «вуглекислотний наркоз». Синдром верхньої та/або нижньої порожнистої вени спричиняє гіпоксію міокарду, загрозливі порушення серцевого ритму, різке зменшення серцевого викиду, циркуляційну гіпоксію.

Різке підвищення внутрішньочерепного тиску та венозне застійне повнокров'я/ крововиливи (насамперед - порушення кровотоку в позбавлених клапанів безіменній та частково в ярмових венах) поглиблюють дихальну недостатність за центральним типом. Застійне повнокров'я паренхіматозних органів посилює синдром поліорганної недостатності $(\mathrm{CПOH})$. При "класичному" варіанті травматичної асфіксії кістковий каркас грудної клітки та ії внутрішні органи не ушкоджені. Торакоабдомінальна компресія нерідко поєднується з аспірацією сипучих тіл, що обтяжує асфіксію. Середній час стискання постраждалих - від 2 до 5 хв. На результат травми впливають тривалість і тяжкість стискання.

Патоморфологічні ознаки: екхімотична маска (ЕM). Нижня межа ЕM $\epsilon$ верхнім рівнем стискання тіла. При стисканні шиї та голови ЕМ відсутня. При стисканні середньої третини грудної клітки ЕМ локалізується вище місця стискання. Колір шкіри обличчя: від синюшно-багряного, червоного до сталевого (чавунного), темно-фіолетового, майже чорного. Крововиливи на слизовій оболонці носа, язика, рота, гортані і супроводжуються хрипкістю голосу, носовим відтінком мови, рідше - афонією. Кровотеча 3 отворів носа, рота, вух. Дрібноточкові крововиливи у тканини головного мозку. Кровиливи у спинний мозок. Крововиливи у шкіру від точкових до плямистих. Вени верхніх кінцівок розширені, переповнені кров'ю, чітко вибухають через шкіру.

Гострота зору може бути ослаблена, іноді відсутнє сприйняття кольорів, особливо червоного. Ін'єкція склер, крововиливи у сітківку ока, субкон'юнктивальні крововиливи, екзофтальм, гемофтальм, а у важких випадках -порушення зору внаслідок крововиливу до ретробульбарної клітковини та склоподібного тіла ока. У важких випадках можлива повна сліпота внаслідок пошкодження зорового нерву. Зіниці розширені, мляво реагують на світло.

Набряк слухових труб, слух здебільшого знижений внаслідок парезу n. vestibulocochlearis, обумовленого застоєм венозної крові в капілярах равлика та кортієвого органу. Смуга стискання на шкірі від предмету. Бронхіолоспазм.

Карміновий набряк легенів (набряк Лакасаня). Він спричиняється повільним стисканням грудної клітки, неспроможним надходженням повітря до легень. Діяльність серця, що продовжується, переміщує більшу частину крові до венозної системи. Вона не може потрапити до великого кола кровообігу в зв'язку з відсутністю припливу венозної крові до легенів. Надходження венозної крові до легенів, а 3 них - до серця утруднене. Перенасичена киснем кров стає карміново-червоною. Інтенсивність забарвлення обумовлена тривалістю життя. Ця ознака найчастіше зустрічається у випадках здавлення однієї половини грудної клітки. Стискання грудної клітки та живота великою вагою викликає швидку смерть, в зв'язку 3 чим набряк не встигає розвинутися. Повнокров'я внутрішніх органів грудей і живота. М'яз серця іноді буває строкатим, з великою кількістю смужчастих крововиливів. Крововиливи у внутрішні органи: залози (щитоподібну, слинні та ін.); корінь язика; м'язи шиї, грудей, живота; під вісцеральну плевру; під епікард; до мисок нирок; у слизову оболонку кишок.

Набряк головного мозку, втрата свідомості. Повнокров'я головного мозку.

Патофізіологічні особливості.

Верхня порожниста вена являє собою судину з тонкими стінками, що розташована в середньому середостінні та оточена відносно щільними структурами (грудна стінка, аорта, трахея та бронхи). По всій довжині вона оточена ланцюжком лімфатичних вузлів. Для верхньої порожнистої вени фізіологічно притаманний низький венозний тиск, що в поєднанні 3 вищенаведеними анатомічними особливостями сприяє ії швидкій обструкції при зовнішньому стисканні. Через верхню порожнисту вену збирається кров від верхніх кінцівок, голови та шиї, верхньої половини грудної клітки. Незважаючи на велику кількість колатералів, останні не здатні замінити порожнисту вену. Ціаноз на нижній половині тіла відсутній, що обумовлено наявністю в системі нижньої порожнистої 
вени великої кількості клапанів, в той час, як у верхній вони досить малі та вразливі. Бар'єром для зворотних хвиль крові $є$ клапани пахвових вен, нижче рівнів яких застійні явища та екхімози не поширюються. Після припинення компресії венозний кровообіг голови та шиї поновлюється.

Потерпілі у свідомості скаржаться на: зміну зовнішності внаслідок набряку шиї та обличчя, біль у грудях, біль у пахових та пахвових ділянках, що заважає рухам, який обумовлений перерозтягненням та порушенням цілісності клапанів вен зворотним бігом крові, що виникає в момент стиснення грудей, задишку, біль у горлі, сиплість голосу, носову кровотечу, головний біль, нудота, запаморочення, тимчасову непритомність, судоми, тимчасові порушення зору та слуху.

N.B.! При нахилах вперед $і$ в положенні лежачи симптоми посилюються.

Основні клінічні ознаки:

Легка ступінь: психічне збудження; обличчя набрякле, невеликий ціаноз; окремі петехії кон'юнктиви; тахіпное.

Середня ступінь: легке або важке оглушення, втрачається орієнтація у просторі та власній особистості; обличчя набрякле, ціанотичне (плетора);

набухання шийних вен; акроціаноз; численні петехії які розповсюджуються по обличчю, шиї, кон'юнктивах очей; інспіраторна задишка; порушення зору.

Важка ступінь: сопор або кома; різкий ціаноз усього тіла; екзофтальм;

набряк обличчя, шиї та верхнього плечового поясу та рук; множинні петехії обличчя, кон'юнктив очей, шиї, рук, ніг; набухання шийних та (інколи) периферичних вен; симптом "декольте" - ціаноз та набряк верхньої половини тулуба з різкою межею (з причини зворотного бігу крові до верхньої порожнистої вени); дихання поверхневе, часте, при відсутності лікування змінюється на агональне ("gasping"), що переходить в апное.

Найбільш значуща рентгенологічна ознака - розширення верхнього середостіння, зазвичай праворуч.

Комп'ютерна томографія - найнадійніший метод візуалізації структур середостіння.

Ускладнення компресійної асфіксії: Постгіпоксична/постаноксична енцефалопатія. Респіраторний дистрес-синдром дорослих. Ателектази легенів. Ексудативний плеврит. Гостре порушення мозкового кровообігу. Гостра серцево-судинна недостатність. Відомі випадки втрати зору, обумовлені крововиливом до склоподібного тіла очного яблука, сітківки, зорового нерву. Можлива втрата слуху з причини крововиливу до середнього вуха. Міоглобінурійний нефроз.

Диференційна діагностика проводиться 3: закритою черепно-мозковою травмою, обтураційною асфіксією, отруєннями, забоєм серця.

Лікування.

Лікування на догоспітальному етапі:

- Звільнити потерпілого від стискання.

- Знеболити (ненаркотичними анальгетиками).

- В легких випадках - забезпечити спокій, холод на судини шиї.

Таблиця 1. Вибір методу респіраторної терапії, заснований на даних пульсоксиметрії (Б.Н. Шах, 2014)

\begin{tabular}{|c|c|c|}
\hline Показники SpO2\% & Оцінка & Допомога \\
\hline $94-98$ & Норма & Ні \\
\hline \multirow{2}{*}{$90-93$} & Помірна & Інгаляція \\
& артеріальна & $50 \%$ кисню \\
& гіпоксемія & $2-3$ л/хв. \\
\hline $85-89$ & Виражена & Інгаляція \\
& артеріальна & $50 \%$ кисню \\
& гіпоксемія & $5-6$ л/хв. \\
\hline$<85$ & Глибока & ШВЛ \\
& гіпоксемія & $100 \%$ кисень \\
\hline
\end{tabular}

- Звільнити від стискаючого одягу.

- Забезпечити прохідність верхніх дихальних шляхів.

- Провести оксигенотерапію або забезпечити доступ свіжого повітря.

- За необхідністю - інтубація трахеї, конікотомія, ШВЛ.

- Фуросемід 40-80 мг або торасемід (торсид) 20 мг в/в для попередження набряку легенів і зменшення набряку мозку. 
- Ввести ГКС: дексаметазн або бетаметазон (бетаспан) - 12-20 мг в/в; 0,9\% розчин натрію хлориду 400, 0 в/в; 4,2\% розчин натрію бікарбонату 200,0 в/в для попередження ураження нирок внаслідок міоглобінемії.

- Провести найпростіші протишокові заходи.

- Госпіталізація у важких випадках до ВІТ, при травматичній асфіксії середньої тяжкості - в травматологічне або торакальне відділення багатопрофільної лікарні.

- Транспортувати постраждалого до $3 О 3$ в напівсидячому положенні.

Кваліфікована медична допомога:

1.У легких випадках після діагностичного спостереження протягом години в приймальному відділенні лікарні хворий може бути відпущений за його вимогою (при повній дієздатності) на амбулаторне лікування за відсутності дихальної недостатності та неврологічної симптоматики, але є доцільним спостереження в клініці протягом першої добі.

2.3неболення ненаркотичними та наркотичними анальгетиками.

3.Оксигенотерапія через назофарінгеальний катетер потоком 6-8 л/хв. та підняття головного кінця ліжка до $30^{\circ}$ (якщо виключено ушкодження хребта). Однак надання кисню майже не впливає на знебарвлення обличчя.

4.Вагосимпатичні блокади.

5.Висока епідуральна блокада, інтраплевральна аналгезія або паравертебральна блокада.

6.При виникненні судомного синдрому внутрішньовенно вводять 2 мл $0,5 \%$ розчину діазепаму (сибазону), 10 мл 20\% розчину натрію оксибутирату.

7.ШВЛ, яку проводять у відділенні інтенсивної терапії протягом від 4 годин до 2-3 діб в режимі, що підтримує рCO $_{2}$ в межах 28-32 мм рт.ст.. Показання - порушення дихання, відсутність свідомості, збудження та підвищення м'язового тонусу, судоми. Тотальну кураризацію та ШВЛ слід проводити до повного усунення судом, гіпертонусу та відновлення ясної свідомості.

8.Профілактика та лікування пневмонії: антибіотикотерапія, інгаляції, тощо.

9.Антикоагулянти та дезагреганти - тільки за впевненістю у відсутності внутрішньочерепних крововиливів.

10.При проведенні інтенсивної терапії необхідно застосування протинабрякових препаратів, зокрема глюкокортикоїдів (30-60 мг преднізолону), салуретиків (40-60мг фуросеміду або 20 мг торасеміду), 5-10 мл 2,4\% розчину теофіліну (еуфіліну) - в/в.

11.При міоглобінурійному нефрозі (сеча бурого кольору) треба ввести крапельно 200-400мл 4\% розчину натрію гідрокарбонату. Лікування - за правилами ведення синдрому тривалого стискання.

$12.10 \%$ розчин кальцію хлориду 10-20 мл в/в для нейтралізації токсичної дії іонів калії на серцевий м'яз.

13.Введення антигіпоксантов: мельдонія (вазопро, мілдроната) - 10,0 мл (100 мг) в/в, тиотріазоліна - 2-4 мл в / в, натрію оксибутирата - 20\% - 10-20 мл в/в, аскорбінової кислоти - 1 3 мл 5\% розчину, для внутрішньовенного крапельного введення розчиняють дозу розчиняють у 50-100 мл 0,9\% розчину натрію хлориду і вводять шляхом повільної інфузії зі швидкістю 30-40 капель на хвилину.

15.L-лізину есцинат 0,1\% - 10 мл в/в на 100,0 мл 0,9\% розчину натрію хлориду двічі на добу (не використовувати разом з цефалоспоринами).

16. Тільки у випадку некерованої гіповолемії: гідроксиетилкрохмаль 130 / 0,42 - 500мл в / в.

Лікування постгіпоксичної енцефалопатії.

1.Насичуюча доза 2000 мг цитиколіну (ліри, нейроцитину), внутрішньовенно в розведенні на 200 мл електролітного збалансованого розчину. Підтримуюча доза аналогічна насичуючій. Вводиться довенно крапельно повільно (до 20 капель за 1 хвилину) протягом 24 годин.

2.В перші 14-20 днів після епізоду аноксії вводять внутрішньовенно крапельно холіну альфосцерат по 1000 мг 2-3 рази на добу з наступним переведенням на пероральний прийом (400 мг 3 рази на добу). Тривалість лікування - 5-6 місяців.

3.Рекомендується добова інфузія препарату амантадину сульфату (ПК-Мерц) по 200 мг 2 рази на добу, протягом 5 днів (швидкість введення одного флакону - не менше 180 хвилин). Потім (за можливістю) рекомендується переходити на таблетовані форми препаратів (по 100 мг 3-4 рази на добу до 4 тижнів).

Спеціалізована медична допомога.

1.Гемодіаліз, плазмаферез за показаннями. 


\section{Прогноз.}

1.Компенсаційні можливості організму залежать від ушкодженої анатомічної ділянки тіла, складу (пористості) стискаючої речовини, сили, площі та напрямку компресії по відношенню до анатомічної вісі, одночасності стискання.

2.Компресія тільки однієї грудної клітини спричиняє смерть протягом 30-50 хв., оскільки рухи діафрагми (насамперед - у постраждалих жіночої статі) не можуть забезпечити достатнього розправлення легенів.

3.Одночасне стискання грудної клітки та черева закінчується повною зупинкою дихання і смерть настає досить швидко.

4.У випадках неодночасного стискання асфіксія розвивається повільно. При стиску тулуба в бічному напрямку патологічний процес перебігає тривало, а в спереду-назад - швидко.

5.Чим більше вага стискаючих предметів, тим скоріше настає смерть.

6.Чим більша пористість маси, що засипала людину, тим довше постраждалий залишається живим під завалом, що обумовлено надходженням атмосферного повітря до дихальних шляхів.

7.Якщо пацієнт виживає досягаючи відділення інтенсивної терапії, то на протязі години виживає близько 90 \% пацієнтів, що не мали супутніх травм, важкий перебіг і смерть можливі при наявності супутніх ушкоджень.

8.Цианотична забарвлення шкіри з 3-8-го дня починає зменшуватися і через 2-3 тижні проходить. Крововиливи на слизових оболонках і склерах розсмоктуються через 4-6 тижні.

9.Одужання та реабілітація тривають до 12 місяців.

\section{ЛІТЕРАТУРА}

1. Беженар І.Л. Компресійна механічна асфіксія при дорожньо-транспортній пригоді// Буковинський медичний вісник, 2013. - т. 17. - № 4 (68). - С. 239-241.

2. Бурдули Н.М. Синдром верхней полой вены/ Клиническая медицина, 2015.- №12 - С.61-63.

3. Досвід застосування амантадину сульфат (ПК-Мерц) у хворих на ішемічний інсульт/ В. А. Гриб, І. І. Тітов, Г. С. Чмир [та ін.] // Галицький лікарський вісник. — 2016. — т.23, № 3 (ч.1). — С. 60-64.

4. Das S., Jena M.K. Homicide by a combination of three different asphyxial methods//Egyptian Journal of Forensic Sciences, 2016. - №6. - P. 298-302.

5. Екстрена медична допомога травмованим на догоспітальному етапі: навч. посіб. для студентів вищ. мед. навч. закл. / В. О. Крилюк [та ін.]; ред. М. І. Бадюк. - Київ: [б. в.], 2016. - 400 с.

6. Криштафор Д.А., Ехалов В.В. Особливості стану постраждалих з політравмою при надходженні до стаціонару// Новини і перспективи медичної науки: зб. мат. XVII конф. студ. та мол. вчених : [під ред. I. B. Твердохліба]. - Дніпропетровськ, 2017. - С.40-41.

7. Механічна асфіксія /Волков О.О., Дзяк Л.А., Схалов В.В., Зозуля О.О., Клигуненко О.М., Лященко О.В., Седінкін В.А., Станін Д.М./за ред. Л.А. Дзяк, О.М. Клигуненко. Дніпро: ЛІРА, 2019. - 188 с.

8. Механическая асфиксия: судебно-медицинская диагностика и оценка: Учебно-методическое пособие / Виттер В.И., Вавилов А.Ю, Бабушкина К.А. и др. - Ижевск, 2016. - 86 с.

9. Общие вопросы политравмы. Экспериментальное моделирование травматических повреждений органов грудной клетки и брюшной полости/под ред. В. В. Бойко, П.Н. Замятина. Харьков:

Издательский дом "ФАКТОР", 2011. - т.1.- 640 с.

10. Политравма: хирургия, травматология, анестезиология, интенсивная терапия/под ред. Ф. Глумчера. К.:"Медицина", 2012. - 736 с.

11. Постгипоксическая энцефалопатия: возможности коррекции / Никонов В. В., Савицкая И.Б., Нудьга А.Н. [и др.] //"Медицина неотложных состояний", 2008. - № 4(17). - С. 65-71.

12. Смерть от сдавления груди и живота в практике судебно-медицинской экспертизы / Л. В. Сибилева // Актуальные вопросы судебно-медицинской травматологии / Под редакцией проф. А. А. Матышева. Л.: ЛСГМИ, 1987. - С. 62-68.

13. Richards C.E., Wallis D.N. Asphyxiation: a review/ Trauma, 2005. № 7. - P. 37-45.

14. Травматическая асфиксия у пострадавшего с тяжёлой сочетанной травмой / Н. Б.Ершова, А. В.Разумейко, В. Н. Ганин и др. // Вестник хирургии имени И.И. Грекова. - 2017 .- №1 .- С. 88-90 .

15. Traumatic asphyxia/ Y.A. Karamustafaoglu, I. Yavasman, S. Tiryaki [et al.], Yoruk Y. // Int. J. Emergency Med. 2010. - v. 3 - № 4. - P. 379-380.

16. Tumram N.K., Ambade V.N., Dixit P.G. Compression asphyxia in upright suspended position/The American Journal of Forensic Medicine and Pathology, 2014. - №35(2). - P. 80-82.

17. Yekhalov V., Khobotova N. Obturative Asphyxia /Development of modern science: the experience of European countries and prospects for Ukraine: monograph / edited by authors. -3rd ed. - Riga, Latvia: "Baltija Publishing", 2019. - p.293-307. 